\title{
Intercropping in Young Oil Palm Plantation under Konkan Region of Maharastra, India
}

\author{
M.S. Gawankar ${ }^{1 *}$, P.M. Haldankar ${ }^{2}$, B.R. Salvi ${ }^{3}$, P.C. Haldavanekar ${ }^{1}$, \\ K.V. Malshe ${ }^{4}$ and H.P. Maheswarappa ${ }^{5}$ \\ ${ }^{1}$ AICRP on Palms (Oil Palm), College of Horticulture, Mulde, Kudal, \\ Sindhudurg (M.S.) 416520, India \\ ${ }^{2}$ Director of Research, ${ }^{3}$ Department of the Horticulture, India \\ College of Agriculture, Dr. B.S.K.K.V., Dapoli, Ratnagiri, India \\ ${ }^{4}$ Mango Research Substation, Rameshwar, Tal. Devgad, India \\ ${ }^{5}$ A.I.C.R.P. on Palms, C.P.C.R.I., Kasargod (Kerala), India \\ *Corresponding author
}

\begin{tabular}{|c|c|}
\hline \multicolumn{2}{|r|}{ A B S T R A C T } \\
\hline & \multirow{6}{*}{$\begin{array}{l}\text { Oil Palm is vertically growing perennial crop attains a height of about } 20 \text { to } 30 \text { meter with } \\
\text { economic life of } 35 \text { years. It is planted on wider space and under good management it } \\
\text { takes three years to utilize entire inter space. Since it is vertically growing perennial crop, } \\
\text { there is ample scope for raising intercrops in oil palm plantations during the initial 3-4 } \\
\text { years. Hence, attempt was made to suggest suitable intercrops in juvenile oil palm garden. } \\
\text { A field experiment was conducted under young oil palm plantation of AICRP on Palms } \\
\text { (Oil palm) project at College of Horticulture, Mulde during the year } 2014 \text { to } 2017 \text { to find } \\
\text { out compatible and profitable intercrops at juvenile stage of the crop. Common crops viz., } \\
\text { Banana, Pineapple and Elephant foot yam were taken as intercrops. Three years study } \\
\text { revealed that, growing banana as an intercrop in oil palm, farmers can get Rs. } 55,833 \text { ha } \\
{ }^{1} \text { from Elephant foot yam Rs. } 61,950 \text { and Rs. } 27,500 \text { from pineapple. The study also } \\
\text { revealed that the net returns were Rs. } 89,549 \text { year }{ }^{-1} \text { in mix cropping with B: C ratio of } 1.83 \\
\text { while it was negative (Rs. } 10,021 /- \text { year }{ }^{-1} \text { ) when oil palm was taken as sole crop. Yield of } \\
\text { oil palm in intercrops was } 10.53 \text { ha }^{-1} \text { whileit was only } 7.64 \mathrm{t} \text { ha }{ }^{-1} \text { in without intercrops. } \\
\text { Thus, study brought out an alternative to make young Oil Palm orchard profitable by } \\
\text { growing Banana, Pineapple and Elephant foot yam as an intercrop up to } 4 \text { years under } \\
\text { South Konkan region of Maharashtra. }\end{array}$} \\
\hline Keywords & \\
\hline $\begin{array}{l}\text { Banana, Pineapple, } \\
\text { Elephant foot yam, } \\
\text { Intercrop }\end{array}$ & \\
\hline Article Info & \\
\hline $\begin{array}{l}\text { Accepted: } \\
\text { 20 November } 2018 \\
\text { Available Online: } \\
10 \text { December } 2018\end{array}$ & \\
\hline & \\
\hline
\end{tabular}

\section{Introduction}

Oil Palm is an unbranched monoecious, monocotyledonous tree attains a height of about 20 to 30 meter having economic life of 35 years. It is recognised as the major source of vegetable oil with an average oil yield level of 4 to 6 tonnes per hector compared to any other oil yielding crop including coconut and groundnut (Vasanthkumar, 2005). It is planted at a wider space of $9 \mathrm{mx} 9 \mathrm{~m} \times 9 \mathrm{~m}$ in a triangular system. It occupies only 5-15\% 
area during the juvenile phase of the garden (Suresh and Rethinam, 2001). Similarly, 60 to $65 \%$ of the area remains vacant in mature oil palm gardens. Active root system of adult palms under good management is mainly concentrated within a radius of 0.5 to $3 \mathrm{~m}$ laterally from the bole and 10-40 cm depth vertically (Suresh et al., 2003). This situation offers an ample scope for effective utilization of horizontal and vertical space for growing intercrops, thus providing additional employment opportunities and income for small and marginal farm families during the initial three years of oil palm cultivation (Reddy and Prasad, 2011). The main objectives of intercropping are effective utilization of space left between two rows of the main crop and out per unit area. Studies conducted by Reddy et al., (2004) on intercropping in oil palm during juvenile phase revealed that there was no adverse effect on growth of oil palm and also intercrops added lot of biomass (varied from $0.5-17$ tha $^{-1}$ ) which can be utilized by oil palm in future.

Under good management oil palm takes three to four years to utilize entire inter space. Intercropping in the interspaced of oil palm is practiced only in India. In other countries where oil palm is grown, intercropping is not practiced because land is not constrained as it is in India. Since it is a perennial crop, there is ample scope for raising intercrops in oil palm plantations during the initial 3-4 years. Farmers have to grow intercrops during the juvenile phase as there will not be income from oil palm crop. Similarly, economic condition and size of land holding of Indian farmer, increased cost of production and FFB price fluctuation are forcing them to go for intercropping in grown up oil palm garden also. Study conducted by Reddi et al., (2015) on intercropping in oil palm proved that growing okra as an intercrop with oil palm generated higher net return compared to other vegetable crops in young oil palm garden. In Maharashtra area under oil palm is increasing through Govt. Schemes and information on growing intercrops in juvenile garden is lacking. With the above background attempt was made to grow suitable intercrops in juvenile oil palm garden.

\section{Materials and Methods}

An investigation was carried out in young oil palm plantation of AICRP on Palms (Oil palm) project at College of Horticulture, Mulde during the year 2014 to 2018. The main objective of the study was to identify suitable and profitable inter crops at juvenile stage of the oil palm orchard. Intercrops were planted by keeping $3 \mathrm{~m}$ radius free around each palm to avoid any competition as suggested by Reddy and Suresh, (2009). Banana variety Kokan Safed Velchi, recommended by the Dr. Balasaheb Sawant Konkan Krishi Vidyapeeth for Konkan region was planted in between the rows of oil palm at a spacing of $2 \times 2.5 \mathrm{~m}$, pineapple variety Queen was planted at 0.45 $\mathrm{x} 0.45 \mathrm{~m}$ in trench having dimension of $3 \mathrm{x} 1 \mathrm{~m}$ (20 plants/ trench) prepared for soil and water conservation along the slop. The elephant foot yam variety Gajendra was grown in kharif during the year 2015, 2016 and 2017at 0.75 x0.75 min a plot size 4.7 x 2 m (12 plants/ plot) in interspaced of oil palm. All crops were fertigated with the recommended dose. During the period from 2015-16 to 201718threeharvest of banana (main crop and ratoon), three harvests of elephant foot yam and only single harvest of pineapple were taken. Yield of mix crops and oil palm were recorded at a time of harvest. Growth and yield observations before and after mix cropping were taken for comparison. Randomly ten leaflets five each from both side of leaf from with and without intercrops were taken from sixteen, seventeen and eighteen number leaf for recording leaf parameters. Average leaf length $(\mathrm{cm})$, width $(\mathrm{cm})$ and leaf 
area $\left(\mathrm{cm}^{2}\right)$ were calculated with the help of Portable leaf area meter (Licor, company, USA. Model. LI-COR, LI 3000C).Oil Palm equivalent yield was calculated as per formula given below:

Oil Palm equivalent yield

$=\frac{\text { Yield of intercrop } \mathrm{x} \text { price of intercrop }}{\text { Price of Oil Palm }}$

The cost of cultivation, economics and benefit cost ratio were worked out based on the prevailing market prices. Intercrops yield were converted to oil palm equivalent yield in order to the significance. The data were statistically analysed by the method described by Gomez and Gomez (1984).

\section{Results and Discussion}

\section{Nutrient status in the soils}

Data regarding nutrient status in the soils at initial stage and after completion of experiment (with and without intercrop plots) are presented in Table 1. Data presented in table revealed that except nitrogen all components were increased in the soils where intercrops were taken. Nitrogen content in the soils in intercrops was $153.66 \mathrm{~kg} \mathrm{~h}^{-1}$ whereas it was $175.61 \mathrm{~kg} \mathrm{~h}^{-1}$ in without intercrops. Decreased in nitrogen content in intercropped soil indicate needs to increase nitrogenous fertilizer while planning intercrops.

\section{Performance of intercrops in oil palm}

The three years data on yield of oil palm as sole and in intercropping system are presented in Table 2. Data in the table revealed that the yield in intercropping system was significantly increased every year than sole crop. It was 5.00, 12.40 and 14.20 $\mathrm{t} \mathrm{ha}^{-1}$ during 2016, 2017 and 2018 respectively. Whereas, it was 3.74, 9.51 and $9.92 \mathrm{t} \mathrm{ha}^{-1}$ during respective years in sole crop. The pooled mean indicated that yield increment in oil palm (FFB) in mix cropping was 36.40 per cent than sole crop. This could be attributed to better growth as indicated by increase in number of leaves and leaf area of the palms under intercropping system. This phenomenon is well supported by Nath et al., (2015) who observed increased in nut yield of coconut in the intercropping situation compared to sole crop.

The yield data of intercrops in mixed cropping system presented in Table 3 revealed that in first year, banana recorded the highest yield (2.9t ha $\mathrm{ta}^{-1}$ )while elephant foot yam recorded significantly highest yield $\left(2.3 \mathrm{t} \mathrm{ha}^{-1}\right)$ during second year. During third year maximum yield was noticed in pineapple $\left(2.5 \mathrm{tha}^{-1}\right)$. Pooled mean data revealed that the maximum yield $\left(2.28 \mathrm{t} \mathrm{ha}^{-1}\right)$ was recorded in banana followed by elephant foot yam $\left(1.82 \mathrm{t} \mathrm{ha}^{-1}\right)$. Decreased in banana yield in subsequent year may be due to ratoon crops. The year $2015-16$ was the first year and pineapple crop was in establishment phase hence yield of pineapple did not obtain during 2015-16. The total yield of oil palm and three intercrop soil palm equivalent yield (OEY) for three years are given in Table 4. Data revealed that total yield in intercrop including OEY of intercrop was $13.09 \mathrm{t} \mathrm{ha}^{-1}$ while in sole crop it was $7.72 \mathrm{t}$ $\mathrm{ha}^{-1}$ which indicated 69.56 per cent yield increment due to mix cropping.

The data on economics of the intercropping system and sole oil palm crop are presented in Table 5 and 6 . The cost of production of sole crop for three years was Rs.1,63,000 $\mathrm{t}$ $\mathrm{ha}^{-1}$ while it was Rs.3,33,629 $\mathrm{ha}^{-1}$ in inter cropping system. The gross returns per hectare for three years was Rs.5, 91,269/- in intercropping and Rs.1, 32,937t ha $\mathrm{ha}^{-1}$ in sole crop. The net returns per year was the highest (Rs. 89,549/-) in intercropping earning Rs.89,570t ha $\mathrm{ha}^{-1}$ as an additional returns than sole crop. The highest B:C ratio (1.83) was noted in intercropping system as against 0.82 in sole oil palm crop as it is in juvenile phase. 
Table.1 Nutrient status in the oil palm plantation

\begin{tabular}{|c|c|c|c|c|c|c|}
\hline Sr. No. & Treatments & $\mathrm{pH}$ & $\begin{array}{c}\mathrm{OC} \\
\left(\mathrm{g} \mathrm{kg}^{-1}\right)\end{array}$ & $\begin{array}{c}\mathrm{N} \\
\left(\mathrm{kg} \mathrm{h}^{-1}\right)\end{array}$ & $\begin{array}{c}\mathrm{P} \\
\left(\mathrm{kg} \mathrm{h}^{-1}\right)\end{array}$ & $\begin{array}{c}\mathrm{K} \\
\left(\mathrm{kgh}^{-1}\right)\end{array}$ \\
\hline $\mathbf{1}$ & Initial Soil sample & 4.78 & 2.06 & 163.07 & 2.17 & 678.70 \\
\hline $\mathbf{2}$ & With Intercrop & 5.07 & 2.61 & 153.66 & 3.58 & 927.3 \\
\hline $\mathbf{3}$ & Without Intercrops & 4.88 & 2.02 & 175.61 & 2.07 & 827.7 \\
\hline
\end{tabular}

Table.2 Yield of oil palm in intercrop and sole crop

\begin{tabular}{|r|c|c|c|c|}
\hline \multirow{2}{*}{ System } & \multicolumn{4}{|c|}{ Oil Palm yield $\left(\mathrm{t} \mathrm{ha}^{-1}\right)$} \\
\hline & $\mathbf{2 0 1 5 - 1 6}$ & $\mathbf{2 0 1 6 - 1 7}$ & $\mathbf{2 0 1 7 - 1 8}$ & Pooled mean \\
\hline Yield of oil palm in mixcrop & 5.00 & 12.40 & 14.20 & 10.53 \\
\hline Yield of sole oil palm & 3.74 & 9.51 & 9.92 & 7.72 \\
\hline SE \pm & 0.03 & 0.11 & 0.11 & 0.04 \\
\hline CD at 5\% & 0.1 & 0.34 & 0.34 & 0.12 \\
\hline $\begin{array}{c}\text { \% increase of yield over sole } \\
\text { crop }\end{array}$ & 33.69 & 30.39 & 43.29 & 36.40 \\
\hline
\end{tabular}

Table.3 Yield of Intercrops in intercropping systems

\begin{tabular}{|c|c|c|c|c|}
\hline \multirow{2}{*}{ System } & \multicolumn{4}{|c|}{ Intercrop yield $\left(\mathrm{t} \mathrm{ha}^{-1}\right)$} \\
\hline & $\mathbf{2 0 1 5 - 1 6}$ & $\mathbf{2 0 1 6 - 1 7}$ & $\mathbf{2 0 1 7 - 1 8}$ & Pooled mean \\
\hline Banana & 2.90 & 2.34 & 1.59 & 2.28 \\
\hline Pineapple & 0.00 & 0.80 & 2.51 & 1.10 \\
\hline Elephant Foot Yam & 0.93 & 2.63 & 1.90 & 1.82 \\
\hline Sole Oil & 0.00 & 0.00 & 0.00 & 0.00 \\
\hline SE \pm & 0.02 & 0.05 & 0.02 & 0.02 \\
\hline CD at 5\% & 0.06 & 0.14 & 0.07 & 0.06 \\
\hline
\end{tabular}


Table.4 Total Oil Palm Equivalent Yield (OEY) of mixed cropping system

\begin{tabular}{|c|c|c|c|c|}
\hline \multirow{2}{*}{ System } & \multicolumn{4}{|c|}{$\begin{array}{c}\text { Total Oil Palm yield }\left(\mathrm{t} \mathrm{ha}^{-1}\right) \\
\text { (Including intercrop yield) }\end{array}$} \\
\cline { 2 - 5 } & $\mathbf{2 0 1 5 - 1 6}$ & $\mathbf{2 0 1 6 - 1 7}$ & $\mathbf{2 0 1 7 - 1 8}$ & $\begin{array}{c}\text { Pooled } \\
\text { mean }\end{array}$ \\
\hline $\begin{array}{c}\text { Oil Palm + Banana+ Pineapple } \\
\text { + Elephant Foot Yam }\end{array}$ & 6.81 & 15.34 & 16.76 & 13.09 \\
\hline $\begin{array}{c}\text { Sole Oil Palm } \\
\text { \% increase of yield over sole } \\
\text { crop }\end{array}$ & 82.08 & 61.24 & 69.02 & 69.56 \\
\hline
\end{tabular}

Table.5 Performance of oil palm and intercrops during 2015-16to 2017-18

\begin{tabular}{|c|c|c|c|c|c|c|c|c|c|c|}
\hline \multirow[t]{2}{*}{ Crops } & \multirow{2}{*}{$\begin{array}{c}\text { Area } \\
\text { covered } \\
\text { under } \\
\text { intercrops }\end{array}$} & \multirow{2}{*}{$\begin{array}{c}\text { Plant } \\
\text { population } \\
\left(\mathrm{ha}^{-1}\right)\end{array}$} & \multicolumn{2}{|c|}{$2015-16$} & \multicolumn{2}{|c|}{$2016-17$} & \multicolumn{2}{|c|}{$2017-18$} & \multicolumn{2}{|c|}{ Mean } \\
\hline & & & $\begin{array}{l}\text { Yield } \\
\left(\mathrm{t} \mathrm{ha}^{-1}\right)\end{array}$ & Gross Rs. & $\begin{array}{c}\text { Yield } \\
\left(\mathrm{t} \mathrm{ha}^{-1}\right)\end{array}$ & Gross Rs. & $\begin{array}{r}\text { Yield } \\
\left(\mathbf{t} \mathbf{h a}^{-1}\right)\end{array}$ & Gross Rs. & $\begin{array}{r}\text { Yield } \\
\left(\mathrm{t} \mathrm{ha}^{-1}\right)\end{array}$ & Gross Rs. \\
\hline Banana & 3600 Sq. m. & 1287 & 2.8 & $70,000 /-$ & 2.3 & $57,500 /-$ & 1.6 & $40,000 /-$ & 2.23 & $55,833 /-$ \\
\hline Pineapple & 752 Sq.m. & 2860 & - & - & 0.790 & $15,800 /-$ & 2.5 & $62,500 /-$ & 1.10 & $27,500 /-$ \\
\hline Elephant Foot Yam & 240 Sq.m. & 1716 & 0.895 & $35,800 /-$ & 2.5 & $87,500 /-$ & 1.9 & $66,500 /-$ & 1.77 & $61,950 /-$ \\
\hline $\begin{array}{l}\text { Oil Palm within } \\
\text { intercrop }\end{array}$ & & 143 & 5.0 & $29,000 /-$ & 12.4 & $71,920 /-$ & 14.2 & $82,360 /-$ & 10.53 & 61,093/- \\
\hline & & & Total & $1,34,800 /-$ & & $2,32,720 /-$ & & $2,51,360 /-$ & & \\
\hline $\begin{array}{l}\text { Oil Palm without } \\
\text { intercrop }\end{array}$ & & 143 & 3.7 & $21,460 /-$ & 9.43 & $54,695 /-$ & 9.79 & $56,782 /-$ & 7.64 & 44,312 \\
\hline
\end{tabular}


Table.6 Total cost and total returns due to intercrops and oil palm without intercrops

\begin{tabular}{|c|c|c|c|c|c|c|c|c|c|c|c|c|}
\hline \multirow[t]{2}{*}{ Particulars } & \multicolumn{3}{|c|}{ Total Cost Rs. } & \multirow{2}{*}{$\begin{array}{c}\text { Gross } \\
\text { Total Cost } \\
\text { Rs. }\end{array}$} & \multicolumn{3}{|c|}{ Gross Returns Rs. } & \multirow{2}{*}{$\begin{array}{c}\text { Total } \\
\text { Gross } \\
\text { Returns } \\
\text { Rs. }\end{array}$} & \multirow{2}{*}{$\begin{array}{c}\text { Net Returns } \\
\text { Rs. }\end{array}$} & \multirow{2}{*}{$\begin{array}{l}\text { Net Returns/ } \\
\text { year Rs. }\end{array}$} & \multirow{2}{*}{$\begin{array}{l}\text { Additional } \\
\text { Returns Due } \\
\text { to } \\
\text { intercrops/y } \\
\text { ear }\end{array}$} & \multirow{2}{*}{$\begin{array}{l}\mathrm{B}: \mathrm{C} \\
\text { ratio }\end{array}$} \\
\hline & 2015-16 & 2016-17 & 2017-18 & & 2015-16 & 2016-17 & 2017-18 & & & & & \\
\hline $\begin{array}{l}\text { Oil Palm with } \\
\text { Intercrops }\end{array}$ & $155,078 /-$ & $84,853 /-$ & $82,698 /-$ & $3,22,629 /-$ & $1,34,800 /-$ & $2,32,720 /-$ & $2,51,360 /-$ & $5,91,269 /-$ & $2,68,648 /-$ & $89,549 /-$ & Rs.89,570/- & 1.83 \\
\hline $\begin{array}{l}\text { Oil Palm } \\
\text { without } \\
\text { Intercrops }\end{array}$ & $53,000 /-$ & $55,000 /-$ & $55,000 /-$ & $1,63,000 /-$ & $21,460 /-$ & $54,695 /-$ & $56,782 /-$ & $1,32,937 /-$ & (-) 30,063/- & $(-) 10,021 /-$ & & 0.82 \\
\hline
\end{tabular}

Table.7 Effect of intercropping on height and number of leaves oil palm

\begin{tabular}{|c|c|c|c|c|c|c|c|c|c|c|c|}
\hline \multirow[t]{2}{*}{ Particulars } & \multicolumn{2}{|c|}{ Av. Height (m) } & \multicolumn{2}{|c|}{ Av. Number of leaves } & \multirow{2}{*}{$\begin{array}{l}\text { Leaf } \\
\text { length } \\
(\mathrm{m})\end{array}$} & No. of & Length & Width & Maximum & Leaflet & \multirow{2}{*}{$\begin{array}{c}\text { Average } \\
\text { Yield } \\
\text { (t/ha) }\end{array}$} \\
\hline & $\begin{array}{c}\text { Before } \\
\text { intercrops }\end{array}$ & $\begin{array}{c}\text { After } \\
\text { intercrops }\end{array}$ & $\begin{array}{c}\text { Before } \\
\text { intercrops }\end{array}$ & $\begin{array}{c}\text { After } \\
\text { intercrops }\end{array}$ & & \multicolumn{5}{|c|}{ After intercrops } & \\
\hline $\begin{array}{l}\text { Oil Palm with } \\
\text { intercrops }\end{array}$ & \multirow[t]{2}{*}{0.96} & 2.61 & \multirow[t]{2}{*}{22.01} & 29.82 & 4.89 & 264.8 & 79.01 & 3.36 & 4.47 & 258.25 & 10.53 \\
\hline $\begin{array}{l}\text { Oil Palm without } \\
\text { intercrops }\end{array}$ & & 2.18 & & 28.42 & 4.18 & 240.9 & 74.28 & 3.17 & 4.31 & 252.80 & 7.72 \\
\hline $\mathrm{SE} \pm$ & & 0.12 & & 0.02 & 0.04 & 0.60 & 0.01 & 0.02 & 0.03 & 0.01 & 0.04 \\
\hline $\mathrm{CD}$ at $\overline{5} \%$ & & 0.33 & & 0.06 & 0.12 & 1.80 & 0.03 & 0.06 & 0.09 & 0.03 & 0.12 \\
\hline
\end{tabular}


Int.J.Curr.Microbiol.App.Sci (2018) 7(12): 2752-2761

Fig.1 Performance of elephant foot yam under oil
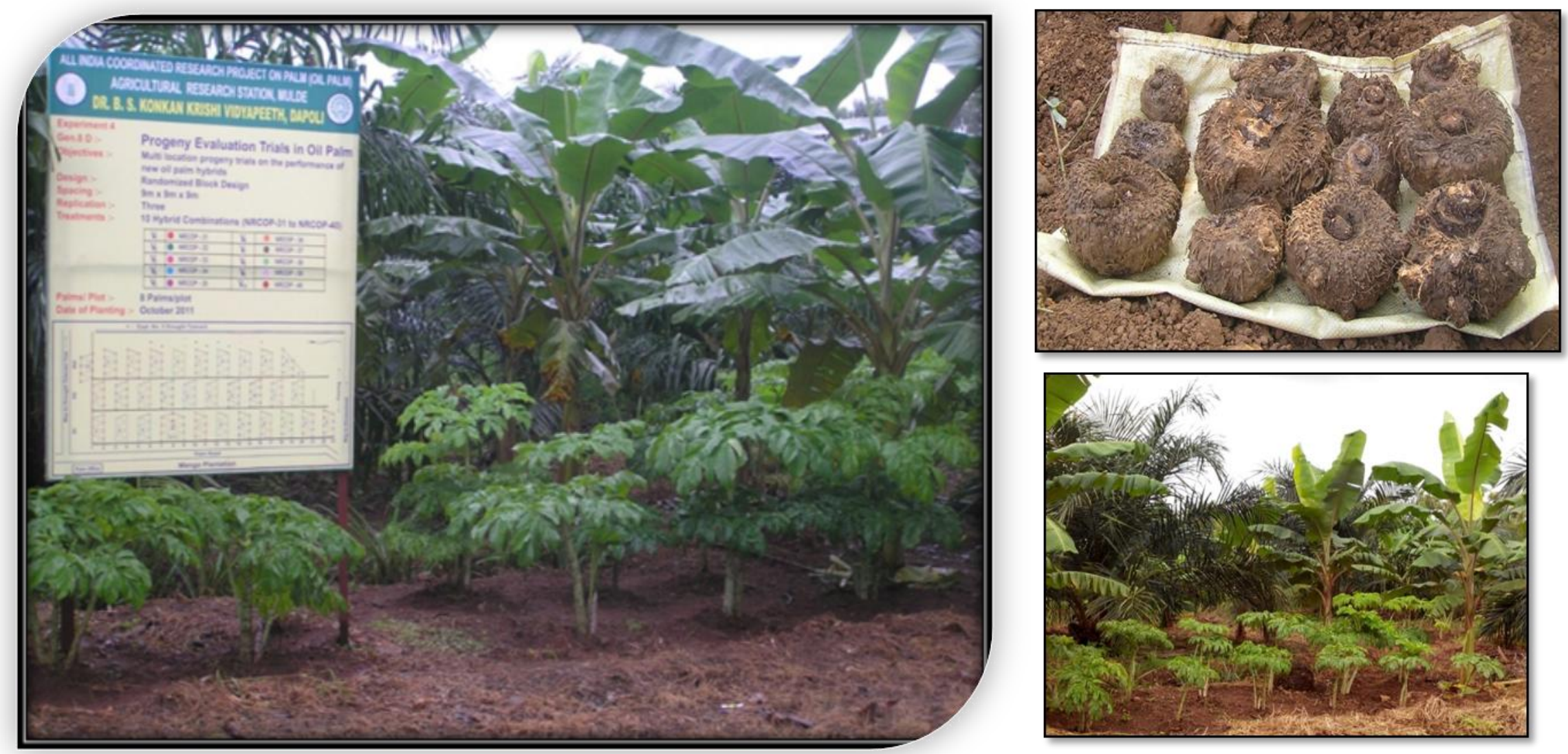
Int.J.Curr.Microbiol.App.Sci (2018) 7(12): 2752-2761

Fig.2 Performance of pineapple under oil palm
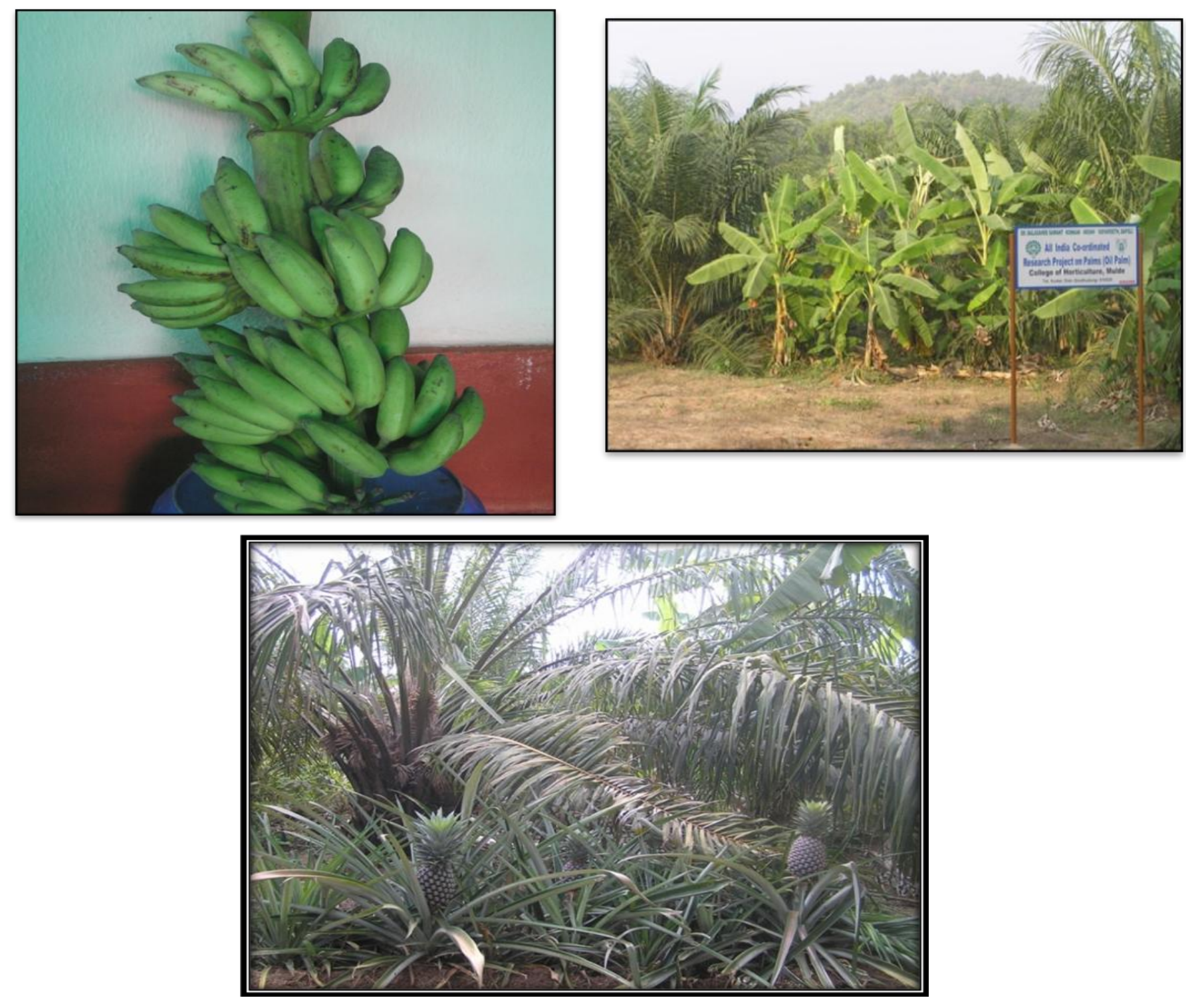
Similar finding were observed by Reddi et al., (2015) when okra was taken as intercrop in oil palm. Reddy and Suresh (2009) found banana was the most profitable crop when compared with turmeric and spider lily.

\section{Effect of intercropping on oil palm}

Data on effect of intercropping in oil palm on morphological parameters are presented in Table 7. It is revealed that palm average height and average number of leaves at a time of planting intercrop were $0.96 \mathrm{~m}$ and 22.01 respectively. After three years of intercropping the palms in intercrop attainted height of $2.61 \mathrm{~m}$ while it was $2.18 \mathrm{~m}$ in without intercrop. This indicated that palm height was increased due to intercropping. This could be due to available moisture and shade. Similarly, after three years of intercropping palms in intercrops produced 29.82 leaves while it was 28.42 in without intercrops which were only 22.01 prior to intercropping. Similarly, palms in intercrops recorded increase in leaf length $(4.89 \mathrm{~cm})$, number of leaflets (264.8), length of leaflet $(79.01 \mathrm{~cm})$, width of leaflet $(3.36 \mathrm{~cm})$, maximum width of leaflet $(4.47 \mathrm{~cm})$, leaflet area $\left(258.25 \mathrm{~cm}^{2}\right)$ and yield also $\left(10.53 \mathrm{t} \mathrm{ha}^{-1}\right)$ as compared to $4.18 \mathrm{~m}, 240.9,74.28 \mathrm{~cm}$, $3.17 \mathrm{~cm}, 4.31 \mathrm{~cm}, 252.80 \mathrm{~cm}^{2}$ and $7.72 \mathrm{t} \mathrm{ha}^{-1}$ respectively in without intercrops. This increased in leaf production and leaf area under intercropping might have resulted in increased in bunch yield of oil palm under intercropping (Nath et al., 2015).

Thus study revealed that the yield of oil palm in intercropping system was triggered 36.40 per cent over sole crop along with the additional yield of intercrops (banana, pine apple and elephant foot yam) which provided the additional returns and highest the $\mathrm{C}: \mathrm{B}$ ratio $(1: 1.82)$ suggesting the compatibility of oil palm for intercropping.
Thus it can be concluded that growing banana, pineapple and elephant foot yam as an intercrop in young oil palm garden up to 4 years is the best preposition for earning additional returns from juvenile oil palm orchard under South Konkan region.

\section{Acknowledgements}

The facilities and cooperation provided by the Principal Scientist and the Director of IIOPR, Pedavegi (A. P.) for the present investigation is thankfully acknowledged. Authors are also thankful to the A. I. C. R. P. on Palms projects and Dr. B. S. K. K. V. Dapoli, Ratnagiri for providing funds for the investigation.

\section{References}

Gomez, K. A. and Gomez, A.A. 1984.Statistical Procedures for Agricultural Research. Second Edition, John Wiley and Sons, Inc. Singapore, $655 \mathrm{pp}$.

Nath, J. C., Deka, K. K., Saud, B. K. and Maheswarappa, H. P. 2015. Intercropping of medicinal and aromatic crops in adult coconut garden under Brahmaputra valley region of Assam. Journal of Plantation Crops, 43(1):1722.

Reddi, S., Patil, G. D. R., Chandravathi, B. and Maheswarappa, H. P. 2015. Studies on vegetables as intercrops in juvenile oil palm plantation and its economics. Karnataka J. Agric. Sci., 28(4): 494496.

Reddy, V. M. and Prasad, M. V. 2011. Banana -A Potential Intercrop in Juvenile oil palm plantation. International J. Oil Palm.8 (1\&2): 5556.

Reddy, V. M. and Suresh, K. (2009). Oil Palm based cropping system under irrigated conditions- Indian scenario. 
Proceedings of National Conference on Oil Palm. SOPOPRAD, Pedavegi. Pp155-161.

Reddy, V. M., Suresh, K., Saraswathi, M.S., Bijimol, M. and Nagamani, Ch. 2004. Intercropping in irrigated oil palm in India. Paper presented during the PLACROSYM XVI- "Reorientation of Plantation Crops Research in the WTO Regime," December 14-17, 2004.

Suresh, K., Reddy, V.M., Sarma, K.N., Bhanusri, A. and Sivasankara Kumar, K.M. 2003.Quantification of root biomass in oil palm grown under basin irrigation. International Journal of Oil Palm, 2(3 \& 4): 39-41.

Suresh, K. and Rethinam, P. 2001. Determination of canopy size in oil palm plantations - A survey. International J. Oil Palm, 2(2): 55.

Vasanthkumar, G.K. 2005. Intercropping in oil palm plantation. Inn. Invited Papers and Abstracts. National Seminar on Research and Development of Oil Palm in India. February 19-20, 2005. Pp. 32.

\section{How to cite this article:}

Gawankar, M.S., P.M. Haldankar, B.R. Salvi, P.C. Haldavanekar, K.V. Malshe and Maheswarappa, H.P. 2018. Intercropping in Young Oil Palm Plantation under Konkan Region of Maharastra. Int.J.Curr.Microbiol.App.Sci. 7(12): 2752-2761. doi: https://doi.org/10.20546/ijcmas.2018.712.312 